\title{
Research on the strategy of intercultural communication competence in college English teaching
}

\author{
Yajie Cui \\ Xijing University, Xi’an 710100, China; \\ cuiyajie001@126.com
}

Keywords: Intercultural communication, English teaching, Communicative competence.

\begin{abstract}
Intercultural communication is the starting point and final destination of English teaching. However, due to various factors, all aspects of current English teaching are biased towards language and cultural knowledge and language competence, and little attention has been paid to the cultivation of intercultural communicative competence. Based on the analysis of the current situation of intercultural teaching in college English, this paper puts forward the strategy of cultivating intercultural communicative competence. The purpose is to guide teachers in college English teaching to pay more attention to the cultivation of students' intercultural consciousness, so as to adapt college English teaching to the needs of China's socio-economic development and international communication.
\end{abstract}

\section{Introduction}

Under the globalization environment, all over the world contact more and more close, frequent cultural exchanges, understanding of cultural diversity[1] and improve the ability of intercultural communication become the premise of individual communication throughout the world. However, due to the significance of education and other factors, education has always emphasized the mastery of English language knowledge[2]. At the same time, for a long time domestic exam-oriented education pattern to be understood as making English teaching the English language forms (pronunciation, semantics, word meaning) and the interpretation of teaching, and cross-cultural communicative functions[3] of English is not too much emphasis on. With the development of cross-cultural communication in recent years, English education[4-5] has become more and more important in cross-cultural communication, and the cultivation of intercultural communication competence has gradually become the basic goal of school English teaching. Intercultural communication involves cultural differences, cultural problem such as strange and cultural psychology of exclusion[6], therefore, cross-cultural communicative competence in practical means of cross-cultural communication problems related to reasonable solving ability. The intercultural competence culture in English teaching means that students should communicate with each other in the context of English culture.

\section{The meaning of intercultural communication}

Intercultural communication refers to the interaction between people from different cultural backgrounds and languages (information sender and information receiver). Different cultural background, communicative language, is bound to cause people's social environment, religion, material and so on, in turn, gave rise to different language habits, social culture, local conditions and customs, habits and customs, etc., make people of different cultural background, communicative language produce certain cultural differences in the process of communication. In order to eliminate this cultural difference, or to reduce cultural differences, it is necessary for communicators to have good intercultural communication skills and to communicate and communicate correctly and effectively. 


\section{The current situation of college English intercultural teaching.}

In the course of investigating the cross-cultural sensitivity of non-English majors, we clearly recognize that non-English majors have weak awareness of cross-cultural communication and low intercultural communicative competence, which leads to inappropriate use of language in cross-cultural communication. The main reasons for the failure of communication are as follows.

On the one hand, in the years of college English teaching, the teachers lack of students' intercultural communicative awareness necessary to guide, lack of attention to the cross-cultural communication ability, make the most of the non-english major college students to the cross-cultural understanding. In the traditional college English teaching, teachers generally focus on the input of language, and pay little attention to the input of the target language. The teaching of language knowledge is more, the training of language skills is more, the teaching of the target language culture knowledge is less, and the practical communication ability is less important. The teaching focus on sex causing students to focus on the isolated, on the understanding of a word or a sentence out of context, from the actual communication environment, in most of the students, learning English is to learn grammar and vocabulary. We ignored in college English teaching for the cultivation of students' intercultural communication, over time, lead to poor students cross-cultural communication ability, make the students' ability of language learning cannot be improved not only, more important is the student for not understand cultural differences in cross-cultural communication and lead to communication problems or failure.

On the other hand, the idea that non-english majors learn English needs to change. Most of the students in order to pass in the university English four, six levels of tests, only pay attention to grammar and vocabulary in college English learning knowledge learning, one-sided think the outline of the university English four, six levels of tests do not cover the target language cultural knowledge, therefore ignoring the culture of learning, or is negative or passive learning. Some students are aware of the importance of the target language culture, but the emphasis is biasedInfluenced by foreign film and television culture and festival culture, some students learning and understanding of the target language culture knowledge limited to film and television works in the surface layer of foreign major holiday, or custom culture, such as ideology, the psychological quality of deep culture, value orientation and behavior way less. A small number of students in cross-cultural knowledge enhancement and cross-cultural communication awareness, both written and oral communication in English expression, there is still ambiguity or communication barriers. This is mainly influenced by the stereotype of the mother tongue, and it is taken for granted that the expression habit in Chinese culture is "passed on" to English, thinking from the cultural perspective of the mother tongue.

\section{The strategy of intercultural communication competence culture}

In view of the cross-culture communication in college English teaching and the importance of English learning for students, how to penetration, cross-cultural communication in teaching practice to improve students' cross-cultural communication ability is a question worthy of careful consideration. Many education scholars put forward some constructive Suggestions, the following based on the predecessors' research results, combining the reality of college English teaching, considering the penetration shall abide by the principle of cross-cultural communication, the following strategies are put forward.

(1) Make full use of the textbook

At present, most of the articles in English textbooks in colleges and universities are from the mainstream media in the UK and the UK, which covers a large number of cultural information that is in line with the reality of western society today. Teachers in the teaching of the article, not only to explain in detail the whole structure of the article, and the sentence patterns, phrases, such as language knowledge, between the lines also cannot ignore the outpouring of cultural knowledge, should be very good use of these cultural knowledge penetration, cross-cultural communication to cultivate the students' intercultural communicative competence. Therefore, teachers should earnestly 
study the teaching, dig into the cultural knowledge in the article, carry on the cultural teaching in the explanation of the article, infiltrate the intercultural communication, to achieve the college English teaching purpose.

(2) Change teaching concept

In college English teaching, "listening, speaking, reading, writing and translating" are important teaching contents, but these are not the whole contents of college English teaching. Some teachers have a knowledge of vocabulary, grammar teaching in the teaching emphasis collocation meanings to recite the words, phrases and sentence pattern structure is almost all the classroom teaching, from the culture background of language learning, makes practical classroom teaching content is insufficient, and boring, students don't interest in learning. Teachers should change the traditional teaching idea, earnestly implement cross-cultural communication teaching, not only pay attention to the students the basic knowledge of teaching, cultivate the students' language skills, more to expand students' knowledge and cultural field of vision, improve students' ability of intercultural communication.

(3) Improved teaching methods

Ever Chen of college English teaching is language form and the internal structure of the structuralist teaching, neglect the connection between the language form and language meaning, cause students lack of cross-cultural communication ability in learning English, a communication error, can't use English correctly. Therefore, teachers should improve traditional teaching methods and practice research based on the needs of intercultural communication teaching, so as to improve the effectiveness of teaching methods.

(4) Build interactive classroom

Cross-cultural communication, advocating swap theme scene, lets the student in the theme of communication gradually formed in the cross-cultural communication ability, and to find and solve problems in the process of communication, the ability of using English language to express meaning right, effective communication with each other. Therefore, in college English teaching, students should design themed situations and build interactive classroom so as to improve students' intercultural communication competence. In addition to the class of communication, but also can create outside the classroom for students cross-cultural communication activities, formed class inside and outside the practice teaching mode of combining English classroom, cultivate the students' intercultural communicative competence.

(5) Carry out various extracurricular activities.

Successful language learning cannot rely on simple classroom learning, and it is difficult to achieve the goal of cultural education for students from a deep level. Rich and colorful extracurricular activities are always beneficial supplement to classroom study. It is one of the ways to broaden the students' cultural horizon by teaching students the cultural knowledge strategies for the use of target language and target language. Teachers can organize a series of lectures regularly, systematically and purposefully from one topic to another.

(6) Compare cultural differences

Correlation method is a more mature method in language teaching, it can be very different from the surface of the find their essence in common between language phenomenon, can also be on the surface is very similar to find out their differences between language phenomenon. There are great differences between English national culture and Chinese culture, and these differences are bound to be reflected in the language. In our country, students are often disturbed by the cultural setting (stercotype) of the national culture, which leads to cultural mistakes in the communication process. In the eyes of the British and American people, such mistakes are more intolerable than speech or grammatical errors. Therefore, in English teaching, teachers should focus on analyzing the cultural differences between students' mother tongue and target language. To strengthen the comparison between the two cultures can help students to eliminate the cultural barriers in English learning and acquire the cultural sensitivity of intercultural communication. 


\section{Conclusion}

Intercultural communication plays an important role in English teaching in colleges and universities, which is not only one of the teaching contents of college English, but also an effective way to improve college students' English language ability. Intercultural communication is not only the language of communication, and intercultural communication, so college English should pay attention to culture education, realize that cultural differences are the biggest obstacle of cross-cultural communication, and then through the effective way to cross-cultural communication teaching, many methods on the cultivation of students' cross-cultural communication ability, causes the student to the correct use of English in communication, reduce the pragmatic mistakes, thus effective and smooth communication with western friends.

\section{References}

[1] E Hoff, C Tian. Socioeconomic status and cultural influences on language. Journal of Communication Disorders. 2016 , 38 (4) :271-278

[2] Knapp, Karlfried. English as an International lingua franca and the Teaching of Intercultural Communication. Journal of English As A Lingua Franca. 2015 , 4 (1) :173-189

[3] L Lamport. The mutual exclusion problem. I. A theory of interprocess communication. Journal of the Acm. 2016,33 (2) :313-326

[4] DV Shah, JM Mcleod, SH Yoon. Communication, Context, and Community. Communication Research. 2016 , 28 (4) :464-506

[5] JL Tracy, D Randles, CM Steckler. The nonverbal communication of emotions. Current Opinion in Behavioral Sciences. 2015 , 3 :25-30.

[6] Yao, Wenjin. Approaching Chineseness : investigating the cultural transfer of behavioural factors in and through Chinese industrial design. Journal of Information Science. 2015 , 36 (4) :517-529. 